\title{
KOMUNIKASI INTERPERSONAL ANTARA ORANGTUA DAN ANAK PASCA PERCERAIAN (Studi Kasus di Banjarmasin Utara Kota Banjarmasin)
}

\author{
Siti Salwa Ratu Ghaisa ${ }^{1)}$ \\ Universitas Islam Kalimantan Muhammad Arsyad Al-Banjari Banjarmasin \\ Email: uwacantik11@gmail.com
}

\begin{abstract}
ABSTRAK
Tujuan penelitian adalah untuk mengetahui komunikasi interpersonal antara orang tua dan anak pasca perceraian. Dan juga untuk mengetahui faktor yang mendukung dan menghambat komunikasi interpersonal antara orang tua dan anak pasca perceraian di Banjarmasin Utara. Metode penelitian menggunakan pendekatan kualitatif dengan tipe penelitian yang digunakan adalah penelitian deskriptif. Data dikumpulkan dengan cara observasi, wawancara dan dokumentasi kepada dua keluarga yang telah bercerai di kecamatan Banjarmasin Utara. Analisis data dimulai dengan melakukan wawancara mendalam dengan informan, setelah melakukan itumembuat transkrip hasil wawancara, dengan cara memutar kembali rekaman hasil wawancara, mendengarkan dengan seksama, kemudian menuliskan kata-kata yang didengar sesuai dengan apa yang ada direkaman tersebut, setelah peneliti menulis hasil wawancara tersebut kedalam transkrip, selanjutnya peneliti harus membaca secara cermat untuk kemudian dilakukan reduksi data. Hasil penelitian menunjukkan bahwa adanya perbedaan bentuk komunikasi interpersonal diantara informan 1 dan informan 2. Pada informan 1 komunikasi interpersonal yang ada didalam keluarga tersebut terlihat baik dan harmonis, tidak ada hambatan saat berkomunikasi kepada anakanaknya. Sedangkan informan 2 komunikasi interpersonal yang terjalin termasuk gagal dan penuh amarah, serta banyak hambatan yang terjadi dalam berkomuniasi antara orang tua dan anak. Penelitian ini menunjukan bahwa teori yang sesuai dengan komunikasi interpersonal antara orang tua dan anak pasca perceraian yaitu, teori pengungkapan diri, teori peran dan teori kebutuhan hubungan.
\end{abstract}

Kata kunci : Komunikasi Interpersonal;Komunikasi Pasca Perceraian; Komunikasi Orangtua dan Anak.

\section{PENDAHULUAN}

Komunikasi Interpersonal yang harmonis antara suami dan istri menjadi sangat penting bagi kelangsungan kehidupan berumah tangga, namun demikian tentunya tidak selamanya sesuai dengan apa yang telah direncanakan,namun ternyata ada beberpa faktor lain yang secara sengaja atau tidak sengaja menghambat keharmonisan hubungan keluarga tersebut. Banyak faktor yang membuat keharmonisan keluarga terpecah yaitu seperti gagal komunikasi, ketidak setiaan, ketidak jujuran, masalah finalsial, kesalah pahaman yang enggan diselesaikan secara langsung, adanya orang ketiga serta kekerasan dalam rumah tangga. Salah satu akibat yang ditimbulkan dengan adanya faktor dan konflik tersebut yaitu adalah perceraian.

Perceraian adalah berakhirnya suatu hubungan rumah tangga seseorang yang di daasari atas esepakatan bersama ataupun sepihak. Ketika kedua pasangan tidak ingin melanjutkan kehidupan berumah tangganya, mereka bisa meminta pmerintah untuk memisahkan. Selama perceraian, pasangan tersebut memutuskan bagaimana membagi harta yang didapatkan saat menikah, hak asuh anak, juga biaya kewajiban untuk mengurus anak.

Berdasarkan data yang telah peneliti himpun dari salah satu sumber detik news (14 Maret 2013), menyebutkan bahwa angka perceraian di Indonesia terjadi peningkatan dari tahun 2011-2012. Berdasarkan data yang diperoleh dari kasus-kasus perceraian yang ditangani pemerintah, bahwa pada tahun 2012 pengadilan agama termasuk Mahkamah Syariah menangani perkara 476.961 kasus. Presentse kasus perceraian ini naik 11,52 persen dari tahun sebelumnya yang menerima 363.041 kasus perceraian. Jumlah keseluruhan perkara yang ditangani itu paling banyak adalah gugat cerai yang dilayangkan istri sebanyak 238.666 atau 58,95 persen, sedangkan perceraian yang dilayangkan suami berupa cerai talak sebanyak 107.780 perkara (26,62 persen) atau setengah dari gugatan yang dilayangkan istri (sumber: Detik News) .

Awal juni 2018 tingkat perceraian di kota Banjarmasin meningkat 5-7 persen dari jumlah perkara pada tahun 2017. Menurut Kepala Pengadilan Agama kelas IA Banjarmasin Dr H Murtadlo SH.MH dari 708 perkara perceraian di tahun 2018, tercatat 545 (70\%) perkara cerai gugat 
(istri), dan $163(30 \%)$ perkara cerai talak (suami) sejak bulan Januari-Mei 2018. Sementara pada tahun 2017, dari 2.361 perkara yang diputus oleh Pengadilan Agama Kelas IA Banjarmasin, (1.175 perkara cerai gugat, dan 305 perkara cerai talak). (Sumber: Data Kementerian Kota Banjarmasin, Tribun Banjarmsin).

Dengan melihat data tersebut peneliti merasa tertarik untuk meneliti model stategi komunikasi interpersonal antara orang tua kepada anak. Berdasarkan studi pendahuluan peneliti dengan cara wawancara pada warga di Banjarmasin, terdapat beberapa kasus perceraian yang terjadi antara orang tua sehingga mengakibatkan berbagai dampak negatif pada anak-anak mereka seperti menjadi pemarah, pemurung dan penyendiri.

Kondisi perceraian menuntut anak untuk menyesuaikan diri dengan keadaan keluarganya. Perceraian adalah transisi kehidupan yang penuh stress bagi anak dalam menyesuaikan diri. Anak harus beradaptasi dengan perubahan dalam keluarga barunya. Tidak semua anak-anak korban perceraian mengalami permasalahan dalam perkembangannya terlepas, dari banyaknya anak korban dari perceraian orangtuanya memilih untuk berprilaku tidak baik, ada juga anak yang menjadikan hidup barunya sebagai motivasi untuk menjadi pribadi yang lebih baik dari dirinya dulu. Hal ini terjadi karena berbeda cara pandang dan berbeda pengalaman yang dirasakan oleh tiap anak korban perceraian kedua orang tuanya.

Cara pandang dan cara berkomunikasi dapat menuntun anak bagaimana menyikapi percerian yang terjadi pada kedua oang tuannya. Banyak anak yang merasa perceraian orang tuanya adalah kesalahan dari anak tersebut, itulah salah satu faktor yang membuat anak terpuruk dan larut dalam perceraian itu. Sikap dan tingkah laku orang tua juga menjadi cerminan untuk anak, jika orang tua tidak dapat mengatasi secara positif perceraiannya itu akan berdampak kepada kesehatan mental anak.

Penelitian ini akan berfokus kepada komunikasi interpesonal antara orang tua kepada anak pasca perceraian yang terjadi di dalam keluarganya. Banyak cara yang dapat dilakukan orang tua untuk terus mengembangkan dan meningkatkan diri anak agar tetap berkembang kearah yang positif. Perkembangan seorang anak sangat dipengaruhi oleh lingkungan keluarga disekitar. Kepercayaan diri merupakan sesuatu yang terbentuk dari interaksi seorang anak dengan orang lain terutama keluarga sebagai orang terdekat dengan cara mempunyai suatu hubungan interpersonal yang tercipta dari adanya komunikasi interpersonal yang berlangsung. Apabila dalam keluarga diciptakan hubungan yang erat satu sama lain, harmonis, dan saling menghargai satu sama lain serta memberikan contoh yang baik akan memberikan pandangan yang positif pada anak dalam membentuk kepercayaan dirinya kembali. Peran keluarga sangat dibutuhakan untuk anak paska perceraian, keluarga yang positif akan melahirkan anak yang positif pula.

Sebuah keluarga yang bercerai pasti menimbulkan dampak negatif dan positif terhadap perkembangan anak mereka. Dampak negatif yang timbul pasca perceraian dapat diminimalkan dengan memberikan perhatian atas perkembangan anak. Perkembangan anak pasca perceraian dapat terganggu, maka dari itu peran orangtua sangat diperlukan dalam fase ini. Walaupun orang tua sudah bercerai tetapi alangkah baiknya masih menjaga kounikasi dengan anak, orang tua harus lebih mementingkan mental anak dari pada dirinya, karna pasca perceraian anak akan dikejutkan dengan ketidak lengkapan keluarga yang sekarang ia miliki.

Banyak cara yang bisa dilakukan para orangtua pasca perceraian untuk meningkatkan harga diri anak yang menurun pasca perceraian. Berdasarkan pemaparan di atas sehingga peneliti tertarik untuk melakukan penelitian yang berjudul "Komunikasi interpersonal antara Orang Tua kepada Anak Pasca Perceraian (di Kecamatan Banjarmasin Utara Kota Banjarmasin).

\section{Tujuan Penelitian}

Tujuan dari penelitian ini yaitu :

1. Untuk mengetahui komunikasi interpersonal antara orang tua kepada anak pasca perceraian.

2. Untuk mengetahui apa saja yang mendukung komunikasi interpersonal antara orang tua kepada anak pasca perceraian.

3. Untuk mengetahui faktor yang menghambat komunikasi interpersonal antara orang tua kepada anak pasca perceraian.

\section{Komunikasi}

Komunikasi menurut Harold Laswell adalah gambaran mengenai siapa mengatakan apa, melalui media apa, kepada siapa, dan apa efeknya. Cara yang baik menggambarkan komunikasi adalah dengan menjawab pertanyaan (Who says What in Which channel to Whom With What Effect?). Berdasarkan definisi Laswell ini dapat diturunkan lima unsur komunikasi yang saling bergantung satu sama lain, yaitu sumber, pesan, media, penerima, dan efek. Menurut Fisher (2002:6), dalam situasi tertentu, komunikasi menggunakan media tertentu untuk mencapai sasaran yang jauh tempatnya atau banyak jumlahnya. Dalam situasi tertentu pula komunikasi dimaksudkan untuk mengubah sikap, pendapat, tingkah laku seseorang atau sejumlah orang, sehingga ada efek tertentu yang diharapkan. 
Proses penyampaian lambang berlangsung dengan menggunakan bahasa sebagai lambang yang mewakili sesuatu, baik yang berwujud maupun yang tidak. Kadang-kadang digunakan lambang lain, diantaranya gerak isyarat anggota tubuh seperti mata, bibir, tangan, gambar, warna. Berdasarkan uraian diatas, dapat disimpulkan bahwa komunikasi adalah usaha untuk menyampaikan pesan atau informasi, baik secara verbal atau non verbal kepada satu atau lebih peneima dengan tujuan untuk mempengaruhi penerima pesan.

\section{Komunikasi Interpersonal}

Menurut kamus besar bahasa Indonesia, interpersonal adalah hubungan antar pribadi. Komunikasi interpersonal disebut juga komunikasi antarpribadi, yang berarti komunikasi yang berlangsung antar dua orang. Menurut Deddy Mulyana (2007:46), komunikasi ini dianggap sebagai yang paling ampuh dalam kegiatan mengubah sikap jika dibandingkan dengan bentuk komunikasi yang lain, alasannya karena komunikasi ini berlangsung secara tatap muka, atau interaksi secara langsung sehingga jika akan merujuk pada konsep feedback, maka feedback akan langsung terjadi. Menurut Effendy (1990:11), komunikasi interpersonal adalah komunikasi yang berlangsung pada umumnya antara dua orang secara dialogis. Komunikasi interpersonal oleh Devito dalam Liliweri $(1991,112)$ didefinisikan sebagai pengiriman pesan-pesan dari seseorang dan diterima oleh orang lain atau sekelompok orang dengan efek dan umpan balik secara langsung. Selanjutnya bahwa komunikasi interpersonal, individu selain menunjukkan perhatian juga menunjukkan seberapa jauh perhatian itu diberikan. Semakin besar interaksi interpersonal yang ada menunjukkan semakin besar perhatian seseorang pada orang lain yang diajak komunikasi, sebaliknya semakin sedikit komunikasi interpersonal yang terjadi semakin kecil orang memperhatikannya. Pace dan Faules (2010:171), mengatakan bahwa komunikasi antar pribadi adalah komunikasi tatap muka antara dua orang atau lebih.

Jenis komunikasi ini dianggap paling efektif untuk mengubah sikap pendapat, atau perilaku manusia berhubung prosesnya yang dialogis. Sifat dialogis itu ditunjukkan melalui komunikasi lisan dalam percakapan yang menampilkan arus balik yang langsung. Jadi komunikator mengetahui tanggapan komunikan pada saat itu juga, komunikator mengetahui dengan pasti apakah pesan-pesan yang dia kirimkan itu diterima atau ditolak, berdampak positif atau negatif. Jika tidak diterima maka komunikator akan memberi kesempatan seluasluasnya kepada komunikator yang bertanya.
Dari uraian diatas dapat disimpulkan bahwa komunikasi interpersonal adalah komunikasi antar komunikator dengan komunikan yang melibatkan dua orang atau lebih terhadap dialog yang terbuka, jujur, dan hangat.

\section{Perceraian}

Perceraian (divorce) merupakan suatu peristiwa perpisahan secara resmi antara pasangan suami-istri dan mereka berketetapan untuk tidak menjalankan tugas dan kewajiban sebagai suamiistri. Mereka tidak lagi hidup dan tinggal serumah bersama, karena tidak ada ikatan yang resmi. Namun mereka yang telah memiliki keturunan, tentu saja perceraian menimbulkan masalah psikoemosional bagi anak-anak. Di sisi lain, mungkin saja anak-anak yang dilahirkan selama mereka hidup sebagai suami-istri, akan diikutsertakan kepada salah satu orang tuanya apakah mengikuti ayah atau ibunya, menurut Olson \& DeFrain (2003:160).

Faktor penyebab perceraian, menurut Turner \& Helms (1995:95) :

1. Ketidakharmonisan dalam rumah tangga. Alasan tersebut adalah alasan yang paling kerap dikemukakan oleh pasangan suami-istri yang akan bercerai. Ketidakharmonisan bisa disebabkan oleh berbagai hal antara lain, krisis keuangan, krisis akhlak, dan adanya orang ketiga. Dengan kata lain, istilah keharmonisan terlalu umum sehingga memerlukan perinci yang lebih mendetail.

2. Krisis moral dan akhlak. Selain ketidakharmonisan dalm rumah tangga, perceraian juga sering memperoleh landasan berupa krisis moral dan akhlak, yang dapat dilalaikannya tanggung jawab baik oleh suami ataupun istri, poligami yang tidak sehat, penganiayaan, pelecehan dan keburukan lainnya yang dilakukan oleh suami ataupun istri, misalnya mabuk, berzinah, terlibat tindak kriminal, bahkan utang piutang.

3. Perzinahan. Disamping itu, masalah lain yang dapat mengakibatkan terjadinya perceraian adalah perzinahan, yaitu hubungan seksual di liar nikah yang dilakukan oleh suami maupun istri.

4. Pernikahan tanpa cinta. Alasan lainnya yang kerap dikemukakan oleh suami dan istri, untuk mengakhiri sebuah perawinan adalah bahwa perkawinan mereka telah berlangsung tanpa dilandasi adanya cinta. Untuk mengatasi kesulitan akibat sebuah pernikahan tanpa cinta, pasangan harus merefleksi diri untuk memahami masalah sebenarnya, juga harus berupaya untuk mencoba menciptakan kerjasama dalam mengambil keputusan yang terbaik. 
5. Adanya masalah-masalah dalam perkawinan. Dalam sebuah perkawinan pasti tidak akan lepas dari yang namanya masalah. Masalah dalam perkawian itu merupakan suatu hal yang biasa, tapi percecokan yang berlarut-larut dan tidak dapat didamaikan lagi secara otomatis akan disusul dengan pisah ranjang.

\section{METODE PENELITIAN \\ Pendekatan Penelitian}

Pendekatan penelitian ini menggunakan pendekatan kualitatif. Peneliti menggunakan metode penelitian kualitatif ini karena berangkat dari judul yang peneliti angkat, yaitu "Komunikasi Interpersonal Antara Orangtua dan Anak Pasca Perceraian". Penelitian kualitatif adalah proses pencarian data untuk memahami masalah sosial yang didasari pada penelitian yang menyeluruh, dibentuk oleh kata-kata dan diperoleh dari situasi yang alamiah. Pada penelitian ini peneliti membuat suatu gambaran kompleks, laporan terperinci dari pandangan responden dan melakukan studi pada situasi yang alami (Creswell 1998:48).

\section{Tipe Penelitian}

Jenis penelitian yang digunakan dalam penelitian ini adalah penelitian deskriptif dengan metode kualitatif. Peneliti mengembangkan pertanyaan pertanyaan kepada informan. Penelitian ini bertujuan untuk menggambarkan sifat peristiwa yang sedang berlangsung pada saat studi yang akan menghasilkan deskriptif berupa kata kata tertulis atau lisan dari informan atau perilaku yang diamati.

\section{Subjek Penelitian dan Informan}

Informan adalah orang yang berada pada lingkup penelitian, artinya orang yang dapat memberikan informasi tentang situasi dan kondisi latar penelitian. Jadi ia harus secara sukarela dan harus banyak memiliki pengetahuan dan pengalaman tentang yang akan di teliti. Kemudian menjadi anggota tim meskipun tidak secara formal, mereka dapat memberikan pandangannya dari dalam tentang nilai-nilai, sikap, bangunan, proses dan kebudayaan yang menjadi latar penelitian setempat.

Yang menjadi subjek penelitian dalam penelitian ini adalah keluarga yang bercerai di Kecamatan Banjarmasin Utara kota Banjarmasin. Informan yang mendukung dalam penelitian ini adalah keluarga Ibu Siah dan keluarga Bapa Rama.

\section{Sumber Data}

Data pada penelitian ini terbagi atas dua, yaitu :

1. Data Primer

Peneliti berusaha mendapatkan data dalam bentuk informasi dan pesan melalui sebuah wawancara kepada orang tua yang bercerai.
Peneliti akan mencari responden atas kriteria yang telah ditetapkan untuk melengkapi informasi mengenai bagaimana komunikasi interpersonal orang tua terhadap anak pasca perceraian.

Keriteria informan penelitian ini, adalah :

a. Pasangan bercerai yang memiliki anak, sebagai informan kunci

b. Kasus perceraian di daerah Banjarmasin Utara

c. Anak dari pasangan bercerai yang berusia 9 tahun, sampai dengan usia 21 tahun

d. Kerabat dekat, yang menjadi informan pendukung penelitian

\section{Data Sekunder}

Untuk infomasi tambahan didalam penelitian ini, peneliti juga mengumpulkan datadata yang bersumber dari website yang berupa artikel, jurnal, dan hasil pra survei peneliti.

\section{PEMBAHASAN}

Komunikasi yang intensif, yang pernah dilakukan ibu Siah hangat, terbuka, dan sarat akan norma dan nilai kehidupan yang disertai dengan contoh riil (pola komunikasi konsensual) yang dilakukan antara orang tua yang bercerai dengan anak mereka seperti yang dilakukan oleh ibu Siah dan mantan suaminya, dapat membentuk konsep diri positif, anak seperti menerima diri sendiri dengan bijaksana, menghargai orang lain, pemaaf, sabar, dan tidak minder walaupun mereka berasal dari keluarga yang tidak utuh.

Dan sebaliknya, apabila kedua orang tua yang bercerai menjalin komunikasi interpersonal dengan anak secara tidak baik, jarang, tertutup, sarat muatan negatif seperti kemarahan, kebencian dan bahkan memberikan contoh yang tidak baik dalam kehidupan sehari-hari di dalam keluarga seperti pada keluarga bapa Rama, maka anak-anak korban perceraian menjadi anak yang tidak menyukai dirinya sendiri, minder, tertutup, pemarah, dan memiliki konsep diri yang negatif lainnya. Anak juga menjadi tidak percaya kepada keluarga dan orang - orang disekitar lagi, anak anak menutup diri dengan dunia luar dan merasa dirinya menjadi seseorang yang tidak diinginkan.

\section{Peran (Role Theory) Komunikasi Interpersonal Orang Tua Dan Anak Pasca Perceraian}

Menurut Kozier Barbara (1995:21), Peran adalah seperangkat tingkah laku yang diharapkan oleh orang lain terhadap seseorang sesuai kedudukannya dalam, suatu sistem. Peran dipengaruhi oleh keadaan sosial baik dari dalam maupun dari luar dan bersifat stabil. Peran adalah bentuk dari perilaku yang diharapkan dari seesorang pada situasi sosial tertentu. Sedangkan, Abu Ahmadi (1982:129-130) mendefinisikan peran sebagai suatu kompleks pengharapan manusia 
terhadap caranya individu harus bersikap dan berbuat dalam situasi tertentu berdasarkan status dan fungsi sosial individu tersebut.

Dari definisi diatas maka dapat disimpulkan pengertian teori peran menurut John E Farley (1992:88-89) adalah perspektif dalam sosiologi dan psikologi sosial yang menganggap sebagian besar kegiatan sehari-hari menjadi pemeran dalam kategori sosial (misalnya ibu, manajer, guru). Setiap peran sosial adalah seperangkat hak, kewajiban, harapan, norma dan perilaku seseorang untuk menghadapi dan memenuhi. Peran adalah seperangkat tingkah laku yang diharapkan oleh orang lain terhadap seseorang sesuai kedudukannya dalam, suatu hubungan. Peran dipengaruhi oleh keadaan sosial baik dari dalam maupun dari luar dan bersifat stabil. Peran adalah bentuk dari perilaku yang diharapkan dari seesorang pada situasi sosial tertentu .Orang tua yang tetap menjalin komunikasi interpersonal dengan anak akan membuat anak merasa bahagia dengan orang tua walaupun orang tua berpisah. Komunikasi yang dilakukan dianggap paling berpengaruh dalam membentuk hubungan interpersonal. Maka peran orang tua sangat berpengaruh dalam kehidupan anak .

Seperti halnya yang diungkapkan oleh ibu Siah bahwa tidak ada yang berubah drastis pasca perceraian dirinya dan suaminya, yang berubah hanya dirinya dan mantan suami tidak lagi tinggal dalam satu rumah. Kasih sayang, perhatian, tanggung jawab, serta kewajiban ibu Siah dan mantan suaminya sebagai orang tua anak- anak mereka tetap sama seperti sebelumnya tidak ada yang berubah, yang berubah hanya orang tua menjadi saling berjauhan dan tidak tinggal dengan anak-anak.

Hal ini dibuktikan dengan ibu Siah yang tidak melarang anak-anaknya bertemu dengan ayah mereka, dan dirinya yang tetap menjalankan komunikasi yang baik dengan mantan suaminya. Pada hal ini ibu Siah dan mantan suaminya menjalankan perannya yang baik sebagai ibu dan ayah bagi anak-anak mereka. Tidak ada kata berpindah peran atau pun menggantikan peran masing-masing, ibu Siah dan mantan suami tetap dalam peran menjadi kedua orang tua bagi kedua anak mereka. Dan sebagai orang tua yang berperan untuk menyayangi, mendidik dan memberikan kasih sayang seperti layaknya orang tua yang tidak mengalami perceraian.

Karena menurut sjarkawi (2008:18) perceraian merupakan momok yang sangat menakutkan bagi seluruh anak di dunia ini. Namun apabila kedua orang tua yang bercerai tersebut tetap menjalankan perannya sebagai ibu dan ayah sebagai mana mestinya tentu saja anak- anak tersebut tidak akan merasa rendah diri, karna ia tau walaupun ayah dan ibunya tidak tinggal bersama tetapi hubungan kedua orang tua mereka tidak ada yang berubah.

Sedangkan pada keluarga bapa Rama dapat diketahui bahwa orang tua Yudi tidak menjalankan perannya sebagai orang tua dengan baik pasca perceraian, hal ini dapat dilihat dari ungkapan Yudi yang menyebutkan bahwa walaupun tinggal satu rumah dengan ayah mereka sangat jarang dan hampir tidak pernah terjadi komunikasi dan ibunya yang sekarang jauh dan hanya sibuk memikirkan dirinya sendiri. Sehingga melupakan peran mereka sebagai orang tua yaitu memberikan anak-anak mereka perhatian, kasih saying, kepercayaan dan rasa aman. Yudi mengaku ia merasa sangat kecewa dengan orang tua mereka yang melupakan peran mereka sebagai orang tua.

Orang tua sangat berperan penting bagi kelangsungan pertumbuhan anak -anak. Jika orang tua menjalankan perannya sebagai mana mestinya akan berdampak baik bagi anak mereka. Orang tua berperan untuk melindungi, mengasihi dan memberikan perhatian kepada anaknya, jika orang tua melupakan peran mereka itu akan berdampak bagi pertumbuhan anak. Anak-anak yang terbengkalai akan mudah masuk kedalam pergaulan yang salah, ditambah orang tua mereka yang tidak peduli akan membuat anak menjadi hancur.

\section{Kebutuhan Hubungan Interpersonal Orang Tua Dan Anak Pasca Perceraian}

Tujuan hubungan antar pribadi (Human Relations) adalah saling terjadi kepuasan antar yang terlibat dalam komunikasi, artinya interaksi komunikasi berjalan dengan baik agar tercapai suatu tujuan. Dalam melaksanakan proses interaksi komunikasi manusia berusaha agar terjadi saling adanya pengertian, saling merasakan, saling menyadari kebutuhan masing-masing baik biologis maupun psikologis. Hubungan antar manusia dapat terjadi dalam situasi dan kondisi bermacam-macam serta berbagai lapangan kehidupan, namun tujuannya adalah kepuasan bersama antar pelaku komunikasi.

Hubungan interpersonal antara orang tua dan anak sangat penting untuk menjaga komunikasi yang baik antara orang tua dan anak. komunikasi yang terjalin antara orang tua dan anak dalam suatu ikatan keluarga dimana orang tua bertanggung jawab memenuhi kewajibannya untuk memberikan kasih sayang, perlindungan, pendidikan kepada anak-anak mereka sehingga meningkatkan rasa percaya diri kepada anak.

Dalam kasus keluarga bapa Rama, adanya kekurangan hubungan komunikasi interpersonal dalam antara orang tua dengan anak membuat pertumbuhan menjadi kurang berkembang. Perceraian yang terjadi pada kedua orang tuanya membuat Yudi merasakan kekurangan kasih sayang. Hubungan orang tua dan Yudi semakin 
menjauh dan membuat kepercayaan Yudi akan kasih sayang dan perhatian semakin hilang.

Sedangkan untuk keluarga ibu Siah, walaupun ibu Siah sudah bercerai, tetapi ibu Siah selalu memastikan bahwa komunikasi interpersonal antara anak-anak dan orang tua selalu terjaga. Hubungan ibu Siah dengan anak selalu ia jaga agar anak merasakan kepercayaan akannya kasih sayang dan tidak menjadikan anak kekurangan rasa percaya diri. Mantan suami ibu Siah pun tetap menjalin hubungan yang baik dengan anak - anak tanpa mengurangi sedikitpun kasih sayang.

\section{Self Disclosure (Pengungkapan Diri) Orang Tua Dan Anak}

Pengungkapan diri (self-disclosure) adalah proses menghadirkan diri yang

diwujudkan dalam kegiatan membagi perasaan dan informasi dengan orang lain (Wrightsman, 1987:56). Menurut Morton (dalam Sears, dkk., 1999:24) pengungkapan diri merupakan kegiatan membagi perasaan dan informasi yang akrab dengan orang lain. Pada kasus keluarga ibu Siah dimana adanya keterbukaan antara ibu Siah, mantan suaminya dan anak-anaknya, ibu Siah menjelaskan alasan dirinya dan ayah anak- anak harus bercerai tanpa menjatuhkan harga diri ayahnya.

Berbeda dengan kasus keluarga bapa Rama dimana tidak adanya keterbukaan antara Yudi dengan kedua orang tuanya, Yudi bahkan tidak mengetahui bahwa orang tuanya akan bercerai, tidak ada keterbukaan didalam hubungan orang tua dengan anak, Yudi mengatakan "Mereka tidak pernah menceritakan tentang perceraian kepada saya dan adik saya. "

Yudi dan adiknya tidak dapat mengungkapkan perasaannya mengenai kemarahan dan kekesalannya akan perceraian orang tuanya karena kurangnya keterbukaan berkomunikasi antara dirinya dengan ayah ibunya.

Menurut Laswell (1987:47) bahwa keterbukaan sebagai salah satu aspek komunikasi interpersonal merupakan aspek yang sangat penting dalam kualitas komunikasi karena tingkat keterbukaan antara individu yang satu dengan yang lainnya membuka kesempatan bagi individu tersebut memahami satu sama lain.

Seperti halnya dengan keluarga ibu Siah yang memberikan pemahaman kepada kedua anaknya tentang bagaimana alasan orang tua mereka harus bercerai sehingga anak mereka akan mengerti bahwa walaupun orang tua mereka tidak lagi tinggal bersama namun kasih sayang dan perhatian yang diberikan kepada mereka tidak akan pernah berubah.

\section{PENUTUP}

\section{Kesimpulan}

Berdasarkan hasil analisis terhadap komunikasi interpersonal antara orang tua dan anak pasca perceraian di Banjarmasin Utara dapat disimpulkan yaitu :

1. Komunikasi interpersonal yang dilakukan oleh keluarga ibu Siah dan bapa Rama terbilang sangat bertolak belakang. Komunikasi interpersonal di dalam keluarga ibu Siah berjalan sesuai yang ia harapkan. Bantuan dari mantan suami ibu Siah pun menjadikan komunikasi dengan anak-anak menjadi lebih baik. Dengan adanya komunikasi yang baik menjadikan anak-anak ibu Siah mempercayai keputusan orang tuanya. Berbeda dengan orang tua Yudi, komunikasi interpersonal terhadap anak-anaknya terbilang gagal, karena setelah perceraian anak kurang berkembang dengan baik, dan merasa tidak percaya diri juga tertutup.

2. Faktor yang mendukung komunikasi interpersonal di keluarga ibu Siah yaitu adanya kepercayaan dari orang tua kepada anaknya, bahasa yang mudah dimengerti anak-anak, kasih sayang danjuga empati yang dapat mendukung kelancaran berkomunikasi. Sedangkan pada orang tua Yudi tidak ada faktor yang mendukung dikarenakan minimnya penjelasan dan komunikasi terhadap anak-anaknya.

3. Faktor yang meghambat komunikasi interpersonal di keluarga ibu Siah terbilang tidak ada, karena ibu Siah mampu berkomunikasi dengan baik terhadap anak-anaknya dan membuahkan hasil yang baik yaitu seperti kepercayaan anak-anaknya dan keterbukaan. Pada orang tua Yudi terdapat hambatan dalam komunikasi interpersonal. Faktor yang menghambat komunikasi interpersonal orang tua Yudi yaitu adanya perbedaan status didalam keluarga dan juga perbedaan cara pandang serta pendapat. Yang akhirnya menjadikan gagalnya komunikasi interpersonal anak dan orang tua.

\section{Saran}

Dari hasil Penelitian terhadap kedua keluarga tersebut terlihat perbedaan cara berkomuikasi. Peneliti memberikan saran yaitu :

1. Komunikasi yang dilakukan oleh orang tua Yudi seharusnya dilakukan secara intensif dan terbuka agar komunikasi berjalan lancar. Orang tua Yudi terlihat melakukan komunikasi dengan terangterangan menunjukkan rasa kebencian dan kemarahan kepada anak. 
2. Orang tua Yudi seharusnya dapat lebih sering berkomunikasi secara lebih terbuka dalam hal masalah - masalah agar anak merasa dibutuhkan juga dihargai.

3. Diharapkan adanya penelitian baru tentang tema yang sama atau lanjutan yang lebih mendalam berkenaan dengan tema penelitian ini agar para orang tua yang bercerai, anak korban perceraian, maupun kalangan akademisi dapat lebih mengetahui dan mempelajari komunikasi interpersonal pasca perceraian.

\section{REFERENSI}

\section{Buku}

Ahmadi, Abu. (1992). Psikologi Umum. Jakarta : Rineka Cipta.

Alvonco, Johnson. (1998). Practical Communication Skill. Jakarta: Elex Media Komputindo.

Amato, P. R. (2000). The Consequences of Divorce For Adult And Children. Bandung : Eresco.

Baxter, L. A. (1988). A dialectical perspective of communication strategies in relationship development. New York: Wiley.

Creswell, John W. (1998). Research Design: Pendekatan Kualitatif, Kuantitatif. Yogyakarta: Pustaka Pelajar.

Cangara, Hafied. 2006. Pengantar Ilmu Komunikasi. Jakarta: Ghalia Indonesia.

Devito, Josep. A. (1992). Komunikasi Antarmanusia. Jakarta : ProfessionalBooks.

Effendy, Onong Uchjana. (1990). Ilmu Komunikasi, Teori dan Praktek. Bandung : Rosdakarya. (1993). Ilmu, Teori dan Filsafat Komunikasi. Bandung : PT Citra Aditya Bakti.

Farley, John E., 1992. Sociology. New Jersey: Prentice Hall.

Fisher, B. A., \& Adams, K. L. (2006). Interpersonal Communication: Pragmatics Of Human Relationsip. New York : McGeaw-Hill, Inc.

Gunarsa. 2000. Psikologi Praktis: Anak Remaja dan Keluarga. Jakarta: PT BPK Gunung Mulia

Kozier, Barbara, (1995), Peran dan Mobilitas Kondisi Masyarakat, Jakarta : Gunung Agung.

Laswell. Harol. D. (1987). The Stucture and Function of Communication in Society. New York : Harper \& Co.

Lunandi. (2000). Komunikasi Mengena. Yogyakarta: Kanisus. A.G., 1994, Komunikasi Mengenai : Meningkatkan Efektivitas Komunikasi antar Pribadi, Kanisius, Yogyakarta.
Merton, Robert. K. (1993). Social Theory and Social Structure. New York: The Free Press.

Morissan. (2010). Psikologi komunikasi. Bogor : Ghalia Indonesia.

Mulyana, Deddy. (2005). Human Communication. Bandung : Remaja Rosdakarya., (2007). Suatu pengantar Komunikasi. Bandung : Rosdakarya.

Olson, D. H., \& DeFrain, J. (2003). Marriage Family: Intimacy, Diversity, and Strengths. New York: McGraw Hill.

Purwanto. (1998). Komunikasi interpersonal dan keluarga. Yogyakarta : Adikarya Nusa.

Rakhmat, Jalaludin. (2012). Metode Penelitian

Komunikasi. Bandung : Remaja

Rohim, Syaiful. (2009). Teori Komunikasi: Persfektif, Ragam Dan Aplikasi. Jakarta: Rineka Cipta.

Sambas, Saeful. (2013). Komunikasi Interpersonal. Yogyakarta: Graha Ilmu.

Sarwono, S.W. (1999). Psikologi Sosial. Jakarta : Balai Pustaka (2009). Teori-Teori Psikologi Sosial. Jakarta : Raja Grafindo Persada.

Sears, D.O., Freedman, J.L. \& Peplau, L.A. (1999). Psikologi Sosial. Jilid I.Jakarta: Erlangga.

Sjarkawi. (2008). Pembentukan Kepribadian Anak. Jakarta : Bumi Aksara

Sugiyono. (2010). Metode Penelitian Kualitatif, Kualitatif Dan R\&D. Bandung: Alfabeta.

Supratiknya, A. (1995). Komunikasi Antar Pribadi. Yogyakarta : Kanisius. (2000). Tinjauan Psikologis Komunikasi Antarpribadi. Yogyakarta: Kanisius..

Wayne, R. Pace dan Don F. Faules, (2010), Komunikasi Organisasi. Bandung : PT. Remaja Rosdakarya.

\section{Jurnal Ilmiah :}

Arif, I. Muhammad. (2012). Pengaruh Komunikasi Interpersonal dan Lingkungan Keluarga. Jurnal Ilmu Komunikasi. Vol.4. No.2. hlm. 136-156.

Ramadhany. Rio. (2013). Komunikasi Interpersonal Orang Tua dan Anak Dalam Membentuk Perilaku Positif Anak. Jurnal Ilmu Komunikasi. Vol.1. No.3. hal. 112-121.

Setyowati, Yuli. (2005). Pola Komunikasi Keluarga dan Perkembangan Emosi Anak. Jurnal Ilmu Komunikasi. Vol.2. No.1. hlm. 67-78.

Perempuan Bercerai. Jurnal Ilmiah Psikologi Arkhe. Vol.2. No.2. hlm 41

Rujukan Internet

http://www.ssbelajar.net/2012/11/pengolahan-datakualitatif.html 
Siti Salwa Ratu Ghaisa

MUTAKALLIMIN; Jurnal Ilmu Komunikasi

Vol 3 No 1 Mei 2020

http://banjarmasin.tribunnews.com/2018/06/06/per ceraian-di-banjarmasin

https://www.academia.edu/7440214/ANALISIS_P

ENELITIAN_KUALITATIF_MODEL_MILES_da n_HUBERMAN 